Shepkaru / The Levantine Review Volume 2 Number 1 (Spring 2013)

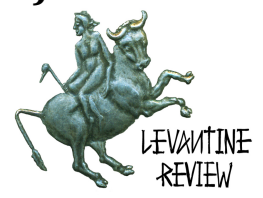

\title{
JEWISH-ARAB RELATIONS THROUGH THE LENSE OF ISRAELI CINEMA; THEN AND NOW
}

\author{
Shmuel Shepkaru*
}

\begin{abstract}
Israeli cinema has presented different aspects of the relationship between Israeli Jews and Arabs. These aspects encompass topics such as personal friendships and conflicts, homosexual and heterosexual affairs, gender issues, politics and wars, and questions of identity. ${ }^{1}$ This article focuses on the presentations of the relationships between Jews and Arabs and their desire for normalization and peace. The movies under discussion have been chosen because they denote different cinematic trends in dealing with this complicated issue of normalization and peace between the two sides. Although primarily expressing the views of their screenwriters and directors, these movies also reveal some of the sentiments that existed in Israeli society at the time of their filming. The movies, therefore, provide a contemporaneous barometer for moods in Israeli society regarding the prospects of peace between Jews and Arabs. To explore the reasons behind these moods, this article will present the changing trends in the Israeli cinema and analyze them against the historical, political, cultural, and social backgrounds in which they were produced.
\end{abstract}

Already early Israeli movies such as Oded the Wanderer (Chaim Halachmi, 1932,) Sabra (Aleksander Ford, 1933,) and Out of Evil (Joseph Krumgold, 1952,) included

\footnotetext{
1 Some of these aspects are discussed in Miri Talmon, and Yaron Peleg, Israeli Cinema Identities in Motion (Austin: University of Texas Press, 2011), part VI and by Gilad Padva, "Discursive Identities in the (R)evolution of the New Israeli Queer Cinema," ibid, 313-325; Raz Yosef, Beyond Flesh: Queer Masculinities and Nationalism in Israeli Cinema (New Brunswick, N.J.: Rutgers University Press, 2004). Yosefa Loshitzky, Identity Politics on the Israeli Screen (Austin, TX: University of Texas Press, 2001), chaps. 6-7; also on identity and passing Carol Bardenstein, "Cross/Cast: Passing in Israeli and Palestinian Cinema," in Rebecca L. Stein, Rebecca and Ted Swedenburg, Palestine, Israel, and the Politics of Popular Culture (Durham: Duke University Press, 2005), 99-125.
} 


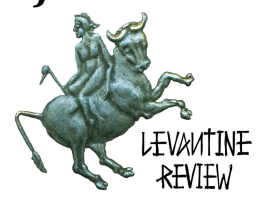

Arabs in their presentations of the Zionist narrative. ${ }^{2}$ Focusing on the agricultural, technological, and social achievements of the early Jewish pioneers (halutzim,) early movies tend to present Arabs almost in the "background" as part of the landscape.

A serious discussion about Jewish-Arab relations started with the Israeli movies of the late 1970s and early 1980s. Especially in the so-called political movies of the $1980 s,{ }^{3}$ one often sees a great deal of self-criticism for mistreating and misunderstanding Arabs in general and Palestinians in particular. ${ }^{4}$ Such approach toward the Arabs, so implies the criticism of this film era, also reflects no desire for peace and tends to blame the Israeli side for the failure to achieve it.

To support their assertions, the critics have cited even early movies that, in my opinion, do little to support their views. Take for example the 1960 movie They Were Ten. The movie tells the story of ten Russian Zionists trying to establish a Jewish community, a new Yishuv, near an Arab village in early nineteenth-century Palestine. In tune with Edward Said's theory of Orientalism, several scholars have argued that the movie reveals the white European male colonialist nature of the early Zionists. For these scholars, They Were Ten provides another example of the Israeli self-image of the heroic/macho, sophisticated, advanced Jewish settler trying to control the primitive and violent Oriental Arab. ${ }^{5}$

The criticism appears to ignore several scenes that would contradict or, at least, dilute such assertions. Indeed the settlers' leader, Yosef, is the model for the national Zionist hero. ${ }^{6}$ But Yosef's heroic characteristics also evoke the image of the

2 More on the early Israeli cinema in Ariel L. Feldestein's "Cinema in Eretz Israel and the Zionist Movement, 1917-1939," in Israeli Cinema Identities in Motion, 3-15.

3 Ella Shohat has dubbed it "the Palestinian Wave," Israeli Cinema: East/West and the Politics of Representation (Texas, 1989), 238.

${ }^{4}$ Amy Kronish, World Cinema: Israel (Trowbridge, Wiltshire, England: Flicks Books, 1996), 123. Yael ben-Zvi-Morad, "Borders in Motion: The Evolution of the Portrayal of the Israeli-Palestinian Conflict in Contemporary Israeli Cinema," in Miri Talmon, and Yaron Peleg, Israeli Cinema Identities in Motion, 276.

5 For example, Ella Shohat, Israeli Cinema, 43, 46-47; 70-71. Yosefa Loshitzky, Identity Politics on the Israeli Screen, 2; and more generally, chap. 9; 126. Dorit Naaman, "A Rave against the Occupation? Speaking for the Self and Excluding the Other in Contemporary Israeli Political Cinema," in Israeli Cinema: Identities in Motion, 258, 260, 272 n. 12.

6 "[S]haped by rudimentary Zionist ideology," according to Shohat, Israeli Cinema, 57. 


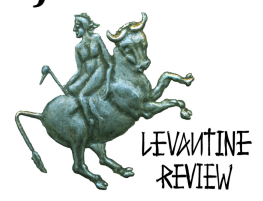

Hollywood hero in classic Westerns. ${ }^{7}$ Already the opening scene of the movie betrays its Western style. It is also true that They Were Ten has an Arab thief and liar. But the movie does not spare the Jews from immoral acts either. The settler Asher steals the group's last piece of bread and lies about it. And Zalman tries to force himself on the married Mania. Such human weaknesses in the movie are well nigh universal, and unrelated to ethnicity or religion per se.

It is also clear that the Jewish settlement is portrayed as primitive, and the Arab village as advanced. The Jewish settlers learn from their Arab neighbors how to work the fields, ride horses, and mostly, how to survive the harsh conditions of the land. Despite the initial suspicion and one case of violence between individuals, the relationship between the two groups becomes peaceful, friendly, and of mutual respect once they get to know each other.

Telling is the settlers' heated discussion over how to solve the Arabs' refusal to share the only well ${ }^{8}$ and how to react to the Arab shepherds who walk their herd through the settlers' field. The settlers purchased the land legally and the deed allowed them to share the water with the Arabs. Still, the settler Zalman wants to "fix things quietly and peacefully," by continuing to draw water at night when the villagers are asleep. He also suggests having more men in the field to deter the two mischievous shepherds. The settler Shimon rejects the idea. "Are we to steal our own water?" he asks. His suggestion is to take their water by force (which is to say by right.) His premise was that they did not come to Palestine to live in a ghetto and continue to be "children of death" - the phrase used in reverence to persecuted Ashkenazi Jews in Eastern Europe. Nor did they come to Palestine for war, replies another settler; they came to Palestine to escape violence and establish an idyllic society based on peace and universal socialist ideals. "Si vis pacem, para bellum" replies yet another. At the end, they decide to get their water in the open. Despite the initial tension, the encounter does lead to violence. The stunned Arabs let the Jews draw their water. Moreover, Yosef initiates a nice gesture toward a frightened Arab girl, which appears to please the village Sheikh (or elder.) Thereafter, sharing the water was no longer an issue. Misunderstanding rather than ideology appears to be the source of the initial confrontation. Once Sheikh Mustafa gets to converse with Yosef and finds out more about his group, a good relationship starts to develop between the two communities, and the two leaders become friends.

${ }^{7}$ Miri Talmon, Bluz la-tsabar he-avud: avurot e-nos algyah ba- olno a haYiśre eli (Tel Aviv: ha-Universitah ha-petutah, 2001), 214.

8 Judd Ne'eman ascribes a mythological dimension to water themes in the early Israeli movies. "The Jar and the Blade: Fertility Myth and Medieval Romance in Israeli Political Films," Prooftexts, Vol. 22, No. 1-2 (Winter/Spring 2002), 141-156. 


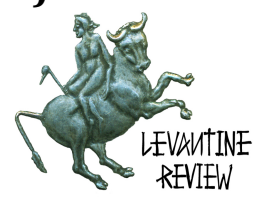

Yet tension between the two groups resurfaces after the settlers caught the Arab horse-thief, Jamal. Jamal's brother manages to escape with the settlers' horse. The settlers refuse to release Jamal without getting their horse back first. The villagers demand Jamal's immediate release and threaten to storm the settlement. This incident, too, presents the settlers with the ideological dilemma of how to solve the quarrel. While the settlers literally stick to their guns, it is Sheikh Mustafa who plays the peacemaker. He warns Yosef that he won't be able to hold back his people much longer. Sheikk Mustafa promises Yosef to find and return the horse. But "for the sake of your people and my people," pleads the Sheikh, release the young man. If not, warns Mustafa, the blood will be on Yosef's hands.

Yosef changes his mind and decides to release Jamal. Violence is averted again and the Arabs go back to their village. Noteworthy is the arrival of the Arabs unarmed. In contrast, the Jews are quick to pull out their guns, out of suspicion and fear perhaps. As in the water scene, miscommunication and misunderstanding play a major role in the confrontation, instigated, this time, by two Arab troublemakers. Still, the incident doses not ruin the relationship between the two communities. Yosef and Sheikh Mustafa shake hands as smiles slowly spread across their faces. They remain good friends.

The settlers' two opposing suggestions with regards to solving conflicts encapsulate the ideology of the early Zionists. On the one hand, they wanted to be in charge of their own fate-self-protection is paramount. On the other hand, in line with their socialist/Zionist beliefs, they hope to co-exist with the Arabs and establish a peaceful and friendly relationship. ${ }^{9}$ Overall, the movie shows that conflicts can be solved, and that more can be achieved by peaceful communication.

The ending of the movie is packed with symbolism. The final scene takes place in a torrential rain after a long period of drought. Symbolism in the scene alludes to the survival of the settlement, and to the successful revival of the Jewish state. Not least important is the hope of establishing peaceful relationships with the Arab neighbors. The movie concludes with two prayers heard simultaneously in the torrential rain. An Arab thanks Allah for the rejuvenating rain, while Yosef says the mourning prayer Kaddish over his wife's grave-who had succumbed to Malaria. The Kaddish concludes with a plea for peace.

Clearly, They Were Ten has its fair share of nationalist propaganda. ${ }^{10}$ The movie, however, also captured bits of reality in nineteen-century Palestine. They Were Ten

${ }^{9}$ Based on other scenes, Talmon offers a similar interpretation. Bluz la-tsabar heavud, 96.

10 Talmon, Bluz la-tsabar he-avud, 94-95. 


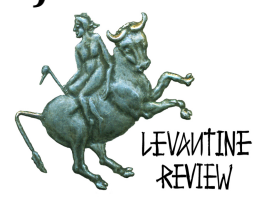

is based on the letters and diaries of the early settlers. And indeed, the Jewish newspapers of the time confirm the existence of close relationships between Arabs and Jews. ${ }^{11}$ In 1909, an editorial in the Hebrew newspaper ha-Tzvi complained that, instead of working, the new Jewish immigrants were seen too often sitting in the Arab cafes of Jaffa, playing Shesh-Besh (Backgammon), and drinking coffee with Arab friends. The Jews, it was written, were learning many things from the Arab culture. Riding horses, which the movie depicts, was one such skill. ${ }^{12}$ There were even reports that when the Arabs celebrated the revolution of the Young Turks in 1908, both Sephardic and Ashkenazi Jews joined the Arabs' parades and celebrations. Conversely, the Arabs are said to have participated in Jewish events. In 1908, Arabs attended Purim plays in Hebrew and Yiddish in Petach Tikva, and it is reported that the Arabs liked more the Yiddish than the Hebrew version. ${ }^{13}$ The point is that, in addition to its nationalistic and propagandist nature, They Were Ten conveyed an authentic desire for peaceful co-existence with Arabs.

As mentioned, the movie came out in 1960, twelve years after Israel's War of Independence and four years after the 1956 Sinai Operation (also known as the Suez War and Mivtza' Kaddesh in Hebrew). ${ }^{14}$ The Israeli military campaign of 1956 came in reaction to devastating terrorist attacks against Israeli civilians and towns, launched by the Fedayeen (Palestinian guerillas) from the Egyptian Sinai Peninsula. Israel emerged victorious and established relative calm in the south. The military victory, the calm that ensued, the new Israeli-French alliance that followed, and the involvement of the UN contributed to an emerging sense of optimism in Israeli society. They Were Ten, therefore, displayed not only its heroes' wishes for peace; it also suggested its viewers stand their ground and insist on their historic rights-as the settlers Yosef and Shimon advocated. But at the same time, the movie reminded us the words of the settler Zalman: "we need to live with [the Arabs] to live with them quietly and peacefully."

11 Boaz Lev Tov, Leisure and Popular Culture Patterns of Jews in Eretz Israel in the Years 1882-1914 as a Reflection of Social Changes (2007). According to Lev Tov, groups of Arabs and Jews moved toward modernization together.

12 See also Anita Shapira, erev ha-yonah: ha-Tsiyonut eha-koa , 1881-1948 [Land of Power] (Tel Aviv: 'Am 'Oved, 1992), 94.

${ }^{13}$ Lev Tov, Leisure and Popular Culture Patterns of Jews in Eretz Israel in the Years 1882-1914.

${ }^{14}$ For more details see Troen, S. Ilan, and Moshe Shemesh, Mivtsa adesh $u$ ma arekhet $\mathrm{Su}$ ets 1956 (Kiryat Śedeh-Boker: ha-Merkaz le-Moreshet Ben-Guryon, 1994); Mordechai Bar-On, The Gates of Gaza: Israel's Road to Suez and Back, 19551957 (New York: St. Martin's Press, 1994). 


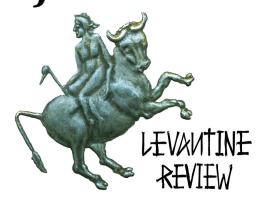

This desire is a recurrent motif in several Israeli movies. Both the desire for peace and the theme of Arab-Jewish friendship come across in Moshe Mizrachi's 1972 movie, I Love You Rosa. Born in Alexandria, Egypt, in 1931, Mizrachi moved to prestate Israel when he was fourteen years old. I Love You Rosa is based on stories Mizrachi heard from his grandmother about her life in late nineteenth-century Jerusalem. The two Jewish protagonists, the adolescent boy Nissim and the young widow Rosa, do not get along with their families and members of the Jewish community. Their true friends are Arabs; Nissim and Rosa find peace of mind and relief in the company of Arabs, not Jews.

The movie's final scene has a predominantly romantic nature. Rosa agrees to marry the now older Nissim. But the scene also reveals both optimism and nostalgia with respect to Jews and Arabs. The dialogue between Nissim and Rosa takes place on a beautiful spring day on the green hills of Jerusalem during a picnic. Both Jews and Arabs participate in the picnic, with Arabic music playing in the background.

One of Mizrahi's objectives in this film was to show his love for Sephardic culture. In addition, his nostalgic depictions show his yearning for the restoration of some peaceful Jewish-Arab past, and his belief in a multicultural co-existence. Because of their Arab culture, Sephardic Jews appear in this film as the better bridge toward this restoration and normalization. ${ }^{15}$

Another film from the same era, Siege, also speaks to a strong yearning for peace. ${ }^{16}$ But Siege also asks questions about what it would take to attain this elusive peace. Focusing on the young war widow Tamar, ${ }^{17}$ the movie portrays the effects of war on individuals and society. The grieving Tamar struggles to rebuild her life. Eli, who replaced her late husband as the commander of an elite combat unite, feels responsible for her and her son's wellbeing. Eli takes upon himself the duty of shielding the beautiful widow from the advances of insincere men. To cheer her up, Eli tells stories about her late husband. Inadvertently, Eli becomes an obstacle in Tamar's attempts to restore normalcy to her life. Out of respect to the fallen war heroes, the people around Tamar expect her to remain the eternal war widow. Like the country itself, Tamar finds herself under siege.

15 A close relationship between Jews and Arabs is the theme of Mizrahi's 1977French movie Madame Rosa, also known as La vie devant soi. 16 Nitzan Ben Shaul, “Siege” (Matzor), in Starim: Ktav Et Lekolno'a Vetelevizia 4 (1989): 2-9.

17 On this theme see Yael Zerubavel, "Coping with the Legacy of Death: The Widow in Israeli Films," in Israeli Cinema: Identity in Motion, 84-95. 


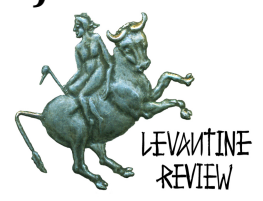

Filmed two years after the 1967 War and during the War of Attrition, the movie is contemporaneous with the post-67 reality. Now Israel has to deal with the Arabs beyond its borders, and the new Arabs within Israel proper, i.e. the Palestinians. At this point, the latter are hardly known to the Israelis. When Tamar, Eli, and members of his unit visit a wounded comrade in the hospital, they see from afar an Israeli officer guarding an injured man. They are surprised to learn that the man is an Arab "terrorist." His family appears in the background for a brief moment. Arabs are now met not only on the battlefield, but also in central Israel.

When Tamar and her late husband's friends travel with their families to explore the new territories, they are surprised to see bustling Arab cities. "Look," says one of the friends, "they have everything here." But no contact is made with the people in the cities. While riding in a car, Tamar sees in the distance from her window and through a chain-link fence Arab women dressed in black morning over the graves of loved ones. The women gradually disappear from the scene as the car drives away. In these scenes, the Arabs appear in the distance, almost faceless, shapeless, unnoticeable. Yet, they are there. This cinematic technique intensifies the theme of unfamiliarity with the new Arabs within. With the redrawing of the borderlines, the Arabs can be seen, but the removal of barriers does not allow for contact. Although Tamar and her friends do not know much about the Arabs they see, they do realize their shared humanity. Both sides are equally vulnerable physically and emotionally; both suffer casualties; both grieve for their dead; both seek normal life.

The question then becomes, how is normal life to be obtained. Siege echoes two solutions. Zevik, the rejected suitor, believes that force is the only solution when dealing with Arabs. The seemingly trivial information about him is significant. He is a TV salesman, a new business in Israel of the late sixties. He never served in a combat unit, and spends much of his time in the United States. Thus he represents the unrealistic view of an uncaring materialistic man oblivious to the tragic consequences of war.

Eli, the military commander, believes that the only solution is "A Franco-Swiss peace." Eli's friends are surprise to hear this solution from him, for it would leave him, a career soldier, unemployed. But for a "Franco-Swiss peace," Eli will happily give up the station, rank, and prestige that his profession provides. He would rather drive a taxi for a living if that's the price for peace.

Of the two solutions it is the former-that is to say, force-that endures. The dangerous consequences of the use of force are illustrated precisely by Tamar's gradual return to normal life. She goes back to her old job as an elementary teacher. She also has a new man in her life. He is a well-to-do bulldozer driver. But just when Tamar finds happiness, her boyfriend is called for reserve duty near Bet Shean. 


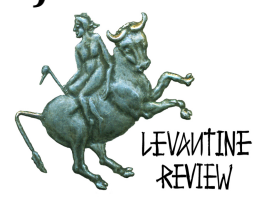

Shortly thereafter, a radio bulletin reports that two bulldozer drivers were killed in that area. Eli drives Tamar up north in search of her boyfriend. Authentic news clips of war and violent social unrest from around the world are interjected into that scene.

What happened to Tamar's boyfriend remains unclear. The movie shifts unexpectedly from the storyline to showing the cast and crew smiling in a dressing room in the midst of filming equipment. Thus fiction and reality are interwoven. Siege is a reminder that the shift from happiness to tragedy might occur anytime, unexpectedly, in the realities of 1969. Nevertheless, the "realistic" part of the movie ends on a happier note. The final scenes express a clear desire for peace: Tamar is seen in her classroom; her charges, very young students are singing a song about their vegetable garden; the camera zooms in on the only word written on the blackboard: "Shalom" (Peace.) If not solely for the generation of 1969, then, Siege hopes that future generations would enjoy this ever elusive idyllic peace.

On the same bittersweet yet optimistic note, Avi Nesher concluded his 1978 The Troupe-the story of a military band that entertains soldiers during the War of Attrition in 1968. The movie soundtrack consists of authentic popular songs of the time. The movie ends with the Troupe and its audience singing enthusiastically the very popular song of the time Shir la-Shalom (Song for Peace.) ${ }^{18}$

The Troupe subtly addressed topics such as, homosexuality, ethnic tension, and peace with the Arabs. By and large, such topics received little attention in the mainstream media. In this context, Shir la-Shalom was more than just a peace song. It delivered a stern warning as well. The song has the fatalities of war asking not to be mourned, for no prayer will ever bring them back from the "black dark pit." Nor do military victories benefit the dead. Dissatisfied with the status quo, the song calls for activism: "Don't say the day will come, /Bring the day /Because it is not a dream." Avi Nesher could not indulge in the wishful thinking that peace would be achieved one day. Shir la-Shalom called for peace activism. In 1978, the dream of peace with Egypt was on the verge of becoming a reality: in 1977 the Egyptian President Anwar El Sadat had made his surprise visit to Israel and called for peace at the Knesset's podium. Sadat's visit was followed by intense negotiations with the rightwing Likud party. It was this context, Sadat's visit and the Likud's hardline ideology, that might have given Avi Nesher reasons to sound his warring; with optimism came the fear of missing historic opportunities of this magnitude.

18 On the song see, Talila Eliram, Bo, shir Ivri: shire Erets Yiśra el, hebe im muzi aliyim e- evratiyim (Haifa University, 2006), 147. 


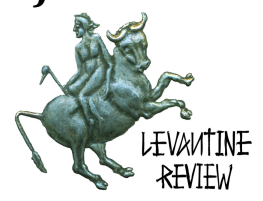

In 1969, however, the song's cynical use of the dead aroused controversy. The IDF's head of Central Command District of the time, Rehavam Ze'evi, banned playing the song on military bases. But such opposition did not dampen the song's popularity. ${ }^{19}$ It was not by chance that in 1995 Prime Minister Yitzhak Rabin read the song at a Tel Aviv mass rally in support of the Oslo Peace Accords. At the end of the rally, the leaders and the crowd sang the song together. As Rabin was leaving the rally, he was assassinated. The piece of paper from which he had read the song was found in his pocket, stained with his blood. This tragic event only amplified the prominence of Shir la-Shalom as the quintessential Israeli peace song.

The movie The Troupe heralded a new trend in Israeli Cinema. Israeli movies of the 1980's tended to blame the Israeli side for committing an historical crime against the Palestinians, and put the onus on Israel for the present failure to achieve peace with Arabs in general. ${ }^{20}$ Feeling strong and secure, Israeli society is depicted in 1980s movies as apathetic and comfortable with the status quo. The dream of making peace into a reality was fading away. Unlike The Troupe, the political movies of the 1980's delivered their criticism explicitly and forcefully. ${ }^{21}$

Late Summer Blues, for example, follows a group of seven high school seniors in the summer of 1970 and during the War of Attrition. This is their last summer before enlisting in the army. Tzvillich was the first to enlist. Shortly thereafter, Tzvillich dies in a training accident. His death looms heavily over his friends throughout the movie. Tzvili's death makes his friends and the audience aware that there is no glory in war. Dying in a training accident, as opposed to dying as a hero in war, does not make a difference for Tzvillich's friends. The equation implies that war casualties are equally unnecessary and preventable, as Tzvillich's accident.

Filmed in 1987, the movie is based on Renen Schorr's 1976 script. The movie captures Schorr's experience as a high school student in 1970. Schorr was among the high school seniors who wrote the famous "Seniors' Letter" to Prime Minister Golda Meir, whom the movie mocks. Following Golda's refusal to grant Nachum Goldman, the President of the World Jewish Congress, permission to meet with the Egyptian President, Gamal Abdel Nasser, the "Seniors" sent their letter to protest the war, the occupation, and Golda's refusal. Why should Israeli youth continue to enlist

19 Talila Eliram, Bo, shir Ivri, 141.

20 The cinematic trend parallels the scholarly treatment of the Arab-Israeli conflict and the Palestinian refugees by the "new historians." Most notable among these "new historians" is Benny Morris, The Birth of the Palestinian Refugee Problem, 19471949 (Cambridge [Cambridgeshire]: Cambridge University Press, 1987).

${ }^{21}$ An early movie of this trend is Daniel Wachsmann's Hamsin (1982). 


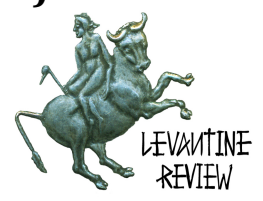

and die at the Suez Canal if peace was not on the leaders' agenda, asked the letter? ${ }^{22}$ Like the writers of the "Seniors' Letter," the movie's pacifist Arale refuses to enlist. He prefers to spray walls in Tel Aviv with anti-war graffiti. Arale also reminds his peers that behind the enemy's line are people "exactly like you and me." But eventually even a hardcore pacifist like Arale cannot defeat the system. Although not giving up on his ideology, Arale does end up enlisting. Thus Arale becomes a tragic rather a heroic character for the "radical left."

At the end, another tragic outcome is revealed. Mossi, the beloved member of the group, died in the October War of 1973. Mossi's death implies that had the politicians acted upon the "Seniors' Letter," or read Arale's graffiti, perhaps the 1973 war could have been prevented. When the movie came out in 1987, Arale's dilemma, to enlist or not, resonated even more strongly because of the presence of Israeli forces in Southern Lebanon. Apart from becoming a commercial success and an Israeli cult movie, Late Summer Blues left its mark on young Israelis who continued writing anti-war letters. ${ }^{23}$

While Late Summer Blues focused on the war with Egypt, other movies focused on the Israeli-Palestinian conflict. Often the Palestinians represented the underdog. To bring attention to Palestinian suffering, many of these movies aimed to place the Israeli viewers in the shoes of the Arabs. In Avanti Popolo (1986) for instance, the Egyptian soldier Khalid, who is trying to get back to the Egyptian side during the last hours of the Six Day War, uses his acting skills to beg for water when coming across an Israeli patrol. Khalid recites from The Merchant of Venice: "I am a Jew. Has not a Jew eyes, emotions, senses, affections, passions?" Khalid knows and understands the Jews. In contrast, the Israeli soldiers fail to see themselves in Khalid, as if they have "no eyes, emotions, senses ...." There is nothing heroic, smart, or attractive about the Israeli soldiers in that movie, while the Egyptians are depicted as the more sophisticated human beings. Moreover, the Israeli soldiers fail to realize their own metamorphosis; when an Israeli soldier asks about Khalid's dramatic speech; "What the F [expletive] is he saying?," his officer responds: "He got the roles mixed up." But

22 For the letter see Morechai Bar-On, In Pursuit of Peace: A History of the Israeli Peace Movement (Washington, D.C.: United States Institute of Peace Press, 1996), 56-8.

${ }^{23}$ Reminiscent of the "Seniors' Letter," 348 reserve combat officers wrote a similar letter to Prime Minister Begin in 1978. Fearing that the peace negotiation with Egypt would fail, the letter urged Begin not to miss this opportunity for peace with Egypt. Bar-On, In Pursuit of Peace, 98-99. In 1982, the Peace Now Movement organized the "400,000 Rally" in Tel Aviv in protest of the First Lebanon War. Although the number is disputed, thousands of reserve soldiers participated in the rally. 


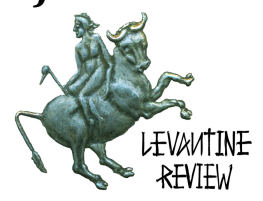

it is the Israeli soldiers here who got the roles mixed up; they fail to show the expected Jewish compassion and understanding. In the larger context, Avanti Popolo holds a "mixed up" Israel responsible for the failure to "see" itself, the present, and the implication of these failures. The result is a continuing suffering for both peoples.

Although the plot revolves around Israelis and Egyptians, the movie also touches upon the Israeli-Palestinian conflict. Palestinian actors play the Egyptians, who speak Palestinian rather than Egyptian-Arabic. Thus the movie gives a voice to the Arabs in general and the Palestinians in particular. ${ }^{24}$ In 1986, the movie served as a reminder that the former Egyptian foe had become a partner in peace. Therefore, the movie implies that, with better understanding and trust, from the Israeli side, peace with the Palestinians is also possible. Rather than giving the audience reason to be content with the Israeli-Egyptian peace, Avanti Popolo indirectly laments the Israeli lack of efforts in achieving a similar peace with the Palestinians.

Of the filmmakers of the time, Haim Bouzaglo provides an interesting example of the 1980's trend in Israeli cinema. Bouzaglo released Fictitious Marriage in 1988. Eldi, the main character in the film, is a married high school teacher experiencing a midlife crisis. He decides to go on vacation to New York. At the airport, Eldi changes his mind and decides not to board his flight, and leaves his suitcase behind. Among his belongings in the suitcase was his military uniform. Eldi thus absconds the main symbol of his Israeli identity, without having even left Israel. The unattended suitcase puts the airport security on alert and is eventually blown up for added precaution. The commotion that his innocent suitcase has caused amuses Eldi. The airport scene pokes fun at the Israeli obsession, if not paranoia, when it omes to security and fear of bombs.

From the airport, Eldi takes a taxi to Tel Aviv and checks into a rundown hotel. He assumes the identity of a naturalized American on a visit to the homeland. Next, Eldi encounters a group of Palestinian laborers at a nearby park. Because of his worn out close, his mustache, his plastic shopping bag, and the traditional Arab kaek he is eating, the Palestinians mistake him for one of their own; a Palestinian laborer. They invite him to join them, once again depicting an Israeli in a Palestinian's shoes. Thus the Israeli becomes the "other" within the "other."

Since Eldi knows only Modern Standard Arabic, he plays the mute among the Palestinians. And as he spends time with the Palestinians, Eldi discovers their

24 On the Israeli-Palestinian context see Carol Bardenstein, "Cross/Cast: Passing in Israeli and Palestinian Cinema," Palestine, Israel, and Politics of Popular Culture, 113115. 


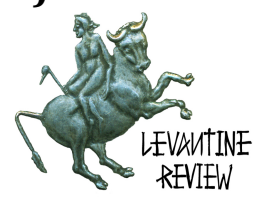

humanity and individuality. He enjoys his new identity, the company of his new friends, and their trust. At one point one of Eldi's new Palestinian friends, Kamal, invites him to his home in Gaza.

When Kamal and Eldi return to Tel Aviv, they bring along with them an old tire. Eldi suspects that they might have brought back a bomb embedded in this tire. He then sees Kamal attaching the tire to a broken swing at a playground and quickly leaving the place. Eldi panics, breaks his feigned mutism, and screams "bomb" in Hebrew. But the only thing that gets blown up in the end was Eldi's fake identity, and it is then that both he and the audience discover that the tire was just that, an "innocent tire," not a bomb. And so, Eldi too falls victim to the same Israeli paranoia that he had mocked in the film's opening scene, at the airport. After spending time with the Palestinians as one of them, Eldi still could not shake off his Israeli stereotypes and prejudices. Ashamed, Eldi collects his belongings and returns to his former life in Jerusalem. Failure to achieve meaningful dialogue with the Palestinians falls squarely on the "mute" Eldi, representing Israeli society as a whole. 25 "Bomb" was the only word he could utter in the presence of his Palestinian friends, even though it was an inapt and inaccurate depiction. The audience is then driven to share in Eldi's sense of shame and embracement, and the Palestinians' sense of betrayal and despair. Even an Israeli who got to know them from the inside ultimately failed to see them for what they were. ${ }^{26}$

In 2006, Haim Bouzaglo made Janem Janem (My Soul, My Soul), with an almost identical plot. The differences, however, are significant. As in Fictitious Marriage, Eldi suffers from a personal crisis. But this time it is clear that Eldi's ailment was a post-traumatic stress disorder, brought about by the loss of his friend in a sniper attack while on a military tour in Jenin. At the advice of his wife, he decides to visit Paris to recuperate. Once again, we see Eldi checking in at the airport. This time, however, the military uniform in Eldi's suitcase is bloodstained with a gaping hole in the center of the shirt. Under the uniform, the security personnel finds the bullet that apparently ripped the hole in the shirt. In contrast to the original version, Eldi does not smile or mock the security system in this serious scene. Eldi even seems to understand why the security personnel had to confiscate these items.

25 According to Bouzaglo, Like Eldi, Israel is also in its forties and suffering a "midlife" crisis. Television interview on "There Were Movies: the 80's," June 6, 2012. ${ }^{26}$ Still, Bouzaglo tries to remain hopeful. During the film's credits Eldi's son is seen squatting down. Thus Bouzaglo shows that perhaps his son's generation would succeed where he has failed. 


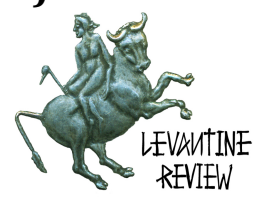

As he was about to board, a group of Turkish and Romanian "guest workers" enter the airport. ${ }^{27}$ Eldi joins them and reenters Israel as one of them. The migrant workers reside in a rundown neighborhood in southern Tel Aviv and work long hours in construction. Despite the terrible conditions, Eldi appears content with his new identity and life among them. Eldi's surreal experience is brought to an end by a Palestinian suicide bombing. Luckily, Eldi survives the blast and reunites with his wife at the hospital.

The contrasting conclusions of Bouzaglo's two films are significant. While in Fictitious Marriage the Palestinians are the victims of Eldi's/Israel's exaggerated paranoia, Eldi does end up being the victim of a real terrorist act in Janem, Janem. While in Fictitious Marriage Eldi could have been accused of being paranoid, in Janem Janem he does become a victim of terrorism indeed because he let his guard down. Rather than blame, the second Eldi gains the audience's sympathy. He is an innocent victim of a brutal and senseless act. The targeting of the foreign workers enhances the brutality and immorality of such attacks. These foreigners had no dog in the Israeli-Palestinian fight. Like the Palestinians of Fictitious Marriage, the laborers in Janem Janem, the new "other" as it were, are only interested in providing for their families by the sweat of their brows.

Several actual suicide bombings that targeted foreign workers have inspired the bombing scene in Janem Janem. ${ }^{28}$ Thus Bouzaglo swings the pendulum of blame between the two sides. Fictitious Marriage was filmed during the First Intifada, which was perceived as a nonviolent Palestinian uprising. Pictures of Israeli soldiers chasing Palestinian stone-throwing children were described in the media as a role reversal between David and Goliath. ${ }^{29}$ Janem Janem was filmed in 2006 while the Second Intifada was still active and the plot is set in 2003, when the Second Intifada was at its peak. Unlike the First Intifada, the Second was markedly more violent.

27 Several movies of the 1990s and 2000s (Noodle, for example) have replaced the Other Palestinian with the foreign workers.

28 On January 6, 2003, a pair of suicide bombers killed 23 and injured more than 100 in a neighborhood of foreign workers in southern Tel-Aviv. This was one of several attacks in the area, which seems to have targeted foreign workers. The plot of the movie is set in 2003.

${ }^{29}$ For example, Mike Shuster: "This was caught on videotape and broadcast to the world, which saw in the Intifada a Palestinian David against the Israeli Goliath." Mike Shuster's series, "The Mideast: A Century of Conflict, Part 6: From the First Intifada to the Oslo Peace Agreement," NPR Morning Edition: October 7, 2002. Zeev Schiff, Ehud Yaari, and Ina Friedman, Intifada: The Palestinian Uprising--Israel's Third Front (New York: Simon and Schuster, 1990), 131. 


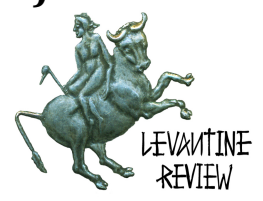

Suicide bombers became its emblem. ${ }^{30}$ In an interview, Bouzaglo described life during the Second Intifada as "a nightmare of terror." 31 A year prior to Janem Janem, Bouzaglo released his movie Distortion, in which he wanted to show for the first time the devastating impact of suicide bombings on innocent Israelis. ${ }^{32}$ Against the background of the First Intifada, Fictitious Marriage could still mock Eldi's exaggerated paranoia and present it as an obstacle to peace. During the Second Intifada, Janem Janem could justify the fears of the first Eldi and present the "nightmare" of terrorism as an obstacle to peace. ${ }^{33}$

Terrorism as an obstacle is conveyed by the 1998 short TV movie Trempistim (Hitchhikers). Hezi, an Israeli salesman picks up three hitchhikers: a religious soldier, a young Israeli woman named Morli, and an Arab Israeli named Mahmud (played by Israeli Arab Jonny Irbid.) ${ }^{34}$ Along the way, the riders poke fun of each others' belief, political views, and outlook on life. Often, the riders shift alliances in their humorous taunts. As expected, Israeli self-criticism is easily displayed through the exchanges between the right-wing soldier and the liberal young woman. Almost uncharacteristically, Mahmud criticizes his own society as well.

30 "From the onset of the Palestinian [Second] intifada in September 2000 through August 2005, 151 Palestinian suicide bombing attacks have been launched against Israeli targets, killing 515 people and injuring almost 3,500 more." Efraim Benmelech and Claude Berrebi, "Human Capital and the Productivity of Suicide Bombers," in Journal of Economic Perspectives, Vol. 21:3 (Summer 2007), 223. 31 Interviewed in January 31 st, 2011 for Cindependent, December $6^{\text {th }}, 2011$. 32 In the same interview from January 31'st, 2011 for Cindependent, Bouzaglo also reveals that he himself witnessed suicide bombings and was fortunate to escape one. Bouzaglo acknowledges that a suicide-bombing scene in his 2004 movie Distortion is based on a personal experience. Five minutes after Bouzaglo had left an ATM at Dizengoff Center in Tel Aviv, a suicide bomber blew up bus number 5 at the same location. According to Bouzaglo, Distortion is the firs Israeli movie about terrorism in Israel; the first Israeli movie to show a terrorist act that is based on a real case of suicide bombing. Although less pronounced, then, the fear of terrorism continues to impact Bouzaglo of Janem, Janem.

33 Interestingly, the Second Intifada appears to have had a similar impact on Benny Morris. Following the violence of the Second Intifada, Benny Morris has altered some of his early views, regarding the Israeli-Palestinian conflict. Morris has blamed the Palestinians for refusing to end the conflict and accept Israel's existence. Benny Morris, 1948: A History of the First Arab-Israeli War (New Haven [Conn.]: Yale University Press, 2008); One State, Two States: Resolving the Israel/Palestine Conflict (New Haven: Yale University Press, 2009).

34 In Distorion, Irbid plays an Arab terrorist. 


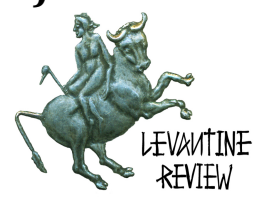

Partially sarcastically, partially seriously, Mahmud assumed at times an Israeli identity and utters Israeli views. When a herd of sheep blocks the road and the two young Arab shepherds reply with obscene gestures and words to the driver's pleas to get out of the way, it is Mahmud who takes offense. He jumps out of the car and snatches the soldier's gun pointing it threateningly at the Arab boys. The three Jewish passengers reprehend him immediately. Mahmud's answer is "Arabs understands only force." But "they are just children," insists Morli, prompting Mahmud's rhetorical reply, "really, just children?" Mahmud's comments echoed views heard on the Israeli streets during the Israeli occupation of Lebanon; a time period that witnessed the so-called "RPG children," the First Intifada, and suicide bombings-phenomena that intensified after the Oslo Accords. In other words, even Mahmud, an Arab, seems suspicious of innocent-looking Arab children. This is a reversal of "role reversals" which we have noticed in some of the movies mentioned earlier; it is the Arab who behaves as the aggressive Jew, while the three Jews behave as the reasoned, patient, and understanding Arab.

Despite their passionate arguments, the riders appear to agree on one thing. As the car radio plays Aviv Geffen's popular song, they agree with his lyrics "We are an [expletive] up generation." 35 Gradually, the tense and suspicious atmosphere in the car becomes relaxed and friendly. It seems that the four, despite their differences, are after all able to overcome their negative stereotypes of the "other."

The hitchhikers' trip comes to an end at a police checkpoint. First, the police officer harasses Mahmud for not having his work permit with him. The rest of the group comes to Mahmud's aid. But when told that a bomb exploded at the spot were the three hitchhikers had been picked up, only Morli continues to declare Mahmud's innocence. Calling attention to herself, the police officer now turns his suspicions to Morli. Searching for drugs, he tries to snatch the sick rabbit Morli was holding in her hands. Mahmud then grabs the police officer's gun and demands that he leave Morli alone: "you feel brave when dealing with women, Arabs, and rabbits,"36 says Mahmud pointing the gun at the officer. Unlike the two Arab shepherds, the Jews take Mahmud's threats seriously, and once again, we see the roles being reversed.

35 Certainly, Geffen is not an arbitrary choice. On 4th of November 1995, Geffen performed his song "Cry For You" at the massive Peace Rally in central Tel Aviv in which Yitzhak Rabin was assassinated. Originally, Geffen wrote "Cry For You" for his young friend who had died in a car accident. The song became popular with Israeli youth and was often heard at the commemorations of young Israeli soldiers who lost their lives. Talila Eliram, Bo, shir Ivri, 147. ${ }^{36}$ Like the word "chicken" in English slang, "rabbit" in Hebrew (and Arabic) also denotes cowardice. 


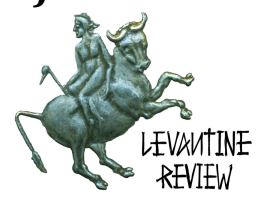

Mahmud's sense of empowerment is short-lived, however. Another police officer draws her gun and pulls the trigger. Morli jumps to protect Mahmud and is hit in his stead. She falls to the ground bleeding. Shouting "cut," the film director interrupts the scene. It is then that the audience discovers that they were watching a movie being filmed within a movie. Before the next take, the audience has a chance to watch the cast members as real people; Jews and Arabs in a happy band of friends. Each person is busy with his or her mundane life; politics, religion, and conflicts are not on their minds. Reality appears more optimistic than the plot. But not for long; a military jeep rushes to the filming site and armed Israeli soldiers jump out. "You must leave the place right away," orders the commander. Terrorists are heading this way, he explains. The cast leaves hastily. Only the rolling camera remains behind to capture a beautiful sunset as gunshots ring out in the background. "Real" terrorism brings an end to potential normalization and friendly co-existence.

\section{CONCLUSIONS}

Taken together the abovementioned movies reflect different tendencies in the Israeli views regarding the Arab-Israeli conflict and relations between the two peoples. Early movies tended to show an Israeli desire for peace with the Arabs and a hope that peace would be achieved one day. Early movies, however, referred to the Arabs collectively, hardly giving them individual voices. Shown from an Israeli perspective, those movies created the impression that peace was mainly an Israeli goal or preoccupation. How the ideal peace could be attained was not discussed, however. Conversely, the movies of the 1980's presented the Arabs as individuals and discussed different aspects of the Israeli-Arab conflict. These political movies focused on the portrayals of the Palestinians and their sufferings under Israeli occupation. The failure to achieve peace was attributed, then, mainly to an insensitive and arrogant Israeli approach, paradoxically consisting of overconfidence and overstressed fear of Palestinian terrorism and mistrust of Arabs. However, especially after the late 90's, suspicion and fear began to appear rather justified, due to waves of suicide bombing following the Oslo Accords. Both sides were then held responsible for the failure to achieve peace. ${ }^{37}$ The result of this failure was well demonstrated by Trempistim.

37 This is not to say, however, that the trend of 1980's movies came to an end. But according to Pablo Utin, contemporary Israeli movies are more restrained when dealing with ideological and political issues than early Israeli films. Contemporary movies, argues Utin, tend to expose only the "tip of the iceberg" and avoid a direct dealing with political issues. Utin, Pablo ar onim be-erets ha- amsinim: ha-

olno a ha-Yiśre eli he- adash, śihot im bama im (Tel Aviv: Resling, 2008), 1327. Carol Bardenstein has a made a similar prediction with respect to passing and identity. "Cross/Cast: Passing in Israeli and Palestinian Cinema," 120. But see, Dorit Naaman, “A Rave against the Occupation?” 257-275. 
Shepkaru / The Levantine Review Volume 2 Number 1 (Spring 2013)

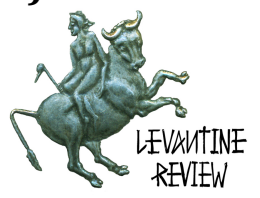

Yet despite the disagreements, Arabs and Jews have no choice but to travel together in a cramped car. Their political, historical, and religiously based arguments and disagreements could only offer a humors voyage through time. Under the serious conditions and atmosphere of the late 1990's and early 2000's the hitchhikers' ride to peace ultimately takes them nowhere. 


\section{FILMOGRAPHY}

Bouzaglo Haim, Fictitious Marriage (Nisu'im Fiktivi'm, 1988).

-----.. Janem, Janem (2006).

Bukai Rafi, Avanti Popolo (1986).

Dickinson Daniel, Hill 24 Doesn't Answer (Giv'a 24 Eina Ona, 1955).

Dienar Baruch, They Were Ten (Hem Hayu Asarah, 1960).

Ford Alexander, Sabra (Tzabar, 1933).

Halachmi Chaim, Oded the Wanderer (Odded ha-Noded, 1932).

Krumgold Joseph, Out of Evil (Mi'klalah le'brachah, 1952).

Mizrachi Moshe, I Love You Rosa (Ani Ohev Otakh Rosa, 1972).

Mizrachi Moshe, Madame Rosa (La vie devant soi, 1977)

Nesher Avi, The Troupe (HaLahakah, 1978).

Renen Schorr, Late Summer Blues (Blues Lahofesh Hagadol, 1987).

Tlalim Asher, Hitchhikers (Trempistim, 1998).

Gilberto Tofano, Siege (Matzor, 1969).

Wachsmann, Daniel, Hamsin (1982).

* Shmuel Shepkaru is Associate Professor of Jewish History in the Department of History at the University of Oklahoma. He is the author of Jewish Martyrs in the Pagan and Christian Worlds (Cambridge University Press, 2001), and his current work focuses on the history of Heaven and Hell. 